Пашкова О. О., науковий співробітник науково-дослідного відділу науково-дослідного центру воєнної історії НУО України імені Івана Черняховського (м. Київ)

\title{
ВІТЧИЗНЯНА ВОСННО-ІСТОРИЧНА ПЕРІОДИКА У ВІЙСЬКОВО-ПАТРІОТИЧНОМУ ВИХОВАННІ КУРСАНТІВ ВВНЗ
}

У статті розглянуто стан вітчизняної наукової періодики на воєнноісторичну тематику. Досліджено створення та розвиток видань освітніх $i$ наукових установ, а також громадських (ветеранських) організацій Украйни. Проаналізовано змістове наповнення иих видань і їх потенціал у поширенні воєнно-історичних знань та популяризації воєнної історії України серед курсантів вітчизняних вищих військових навчальних закладів.

Ключові слова: наукові видання, воєнна історія України, воєнноісторичні знання, курсанти, вищі військові навчальні заклади.

Постановка проблеми. В умовах збройної агресії Російської Федерації проти України підвищилися вимоги до свідомості, мотивації та життєвих настанов особового складу Збройних Сил України. Посилення військовопатріотичного виховання курсантів - майбутніх офіцерів Збройних Сил України стало об’єктивною необхідністю для підготовки їх до відсічі та стримування збройної агресії північного сусіда. Набуття воєнно-історичних знань та формування ціннісного ставлення до воєнно-історичної науки саме зараз, коли пишуться найкривавіші сторінки нашої історії, дасть змогу курсантам вітчизняних вищих військових навчальних закладів краще розуміти сутність подій, учасниками та свідками яких вони стали.

Досягнення воєнно-історичної науки в інтересах військовопатріотичного виховання курсантів військових навчальних закладів активно використовували у радянський час. Однак воєнну історію України 
розглядали лише у контексті “загальноросійської” та “загальнорадянської”. Остаточним табу українська воєнна історія стала у 1970-х роках, коли дослідження за цим напрямом було оголошено проявом буржуазного націоналізму, а знахідки археологів на території України (озброєння, рештки укріплень тощо) не аналізувалися 3 точки зору воєнної історії України [1, с. 5-6]. Про кон'юнктурність системи військово-патріотичного виховання радянської молоді свідчить те, що його наукову основу складало “ленінське вчення про захист соціалістичної Вітчизни". Зміст військово-патріотичного виховання післявоєнного періоду зумовлювався політичним протистоянням із країнами Заходу і складався із багатьох міфологем, таких як “всесвітньоісторичне значення перемоги радянського народу у Великій Вітчизняній війні, розкриття ролі КПРС як організатора і натхненника перемоги над ворогом, викриття фальсифікації історії Другої світової війни” тощо [2, с. 12]. Бібліотеки радянських військових вузів пропонували курсантам матеріали на військово-історичну тематику для пропагування вірності патріотичному i інтернаціональному обов'язку. Чільне місце займали науково-популярні видання, такі як “Военно-исторический журнал” друкований орган Міністерства оборони СРСР. Водночас видань, присвячених воєнній історії України, в УРСР не було.

Сьогодні Російська Федерація як правонаступниця СРСР продовжує насаджувати на пострадянському просторі радянське “бачення” історії колишніх республік. Інформаційне супроводження збройної агресії проти України на 70\% складається 3 воєнно-історичної тематики, перш за все 3 історії Другої світової війни [3, с. 94]. Керівництво Російської Федерації вдається до маніпуляції історичною свідомістю, фальсифікацій та викривлення української історії, у тому числі її воєнної складової. Водночас російська пропаганда поширює дезінформацію про переписування історії в Україні і планомірне налаштовування української молоді проти Росії через систему освіти. Подібні меседжі спрямовані як на російського споживача, так і на населення України [4, с. 366]. 
3 огляду на це використання здобутків вітчизняної воєнно-історичної науки набуває в Україні виняткового значення у процесі військовопатріотичного виховання майбутніх офіцерів Збройних Сил України. Потенціал воєнно-історичної науки як потужного інструменту впливу на свідомість курсантів не вичерпується лише викладанням дисципліни “Історія війн і воєнного мистецтва". Поширення воєнно-історичних знань, а також популяризація вітчизняної воєнної історії серед української молоді може здійснюватися через наукові періодичні видання відповідної тематики.

Мета статті - висвітлити стан вітчизняної наукової періодики на воєнно-історичну тематику, окреслити перспективи іï розвитку, а також з'ясувати іiі роль у військово-патріотичному вихованні курсантів вищих військових навчальних закладів.

Виклад основного матеріалу. Політика пам'яті в Україні довгий час характеризувалася відсутністю чіткої стратегії дій і прогнозування можливих наслідків у найближчій i довгостроковій перспективі. Це стосувалося i розвитку вітчизняної воєнно-історичної науки. Упродовж тривалого часу вона залишалася під впливом радянських стереотипів, особливо події Другої світової війни. Майже не відбувалася переоцінка "героїчних досягнень Червоної армії, неперевершеності радянської зброї, нездоланної сили радянського патріотизму” тощо [5, с. 5]. У кризовому стані перебувала i видавнича справа 3 проблем воєнної історії України. Недостатня кількість фундаментальних наукових праць, енциклопедичної та довідкової літератури, а також фахових періодичних наукових видань унеможливлювала поширення об'єктивних воєнно-історичних знань та популяризацію вітчизняної воєнної історії серед населення України, зокрема молоді.

Поступово ситуація із науковою періодикою на воєнно-історичну тематику почала поліпшуватися. Силами вітчизняних наукових і освітніх установ, а також громадських організацій почали засновуватися видання, що зосередили зусилля вітчизняних дослідників на воєнній історії України. На сьогодні в Україні існує чотири наукових видання на воєнно-історичну 
тематику, внесених до переліку фахових видань України у галузі історичних наук відповідно до наказів Міністерства освіти і науки України, i низка періодичних видань, що випускають громадські (ветеранські) організації України.

Найбільший потенціал у поширенні воєнно-історичних знань серед курсантів і слухачів належить вищим військовим навчальним закладам. Зокрема, у двох провідних вітчизняних ВВНЗ засновано наукові видання, присвячені тематиці воєнної історії: “Воєнно-історичний вісник” Національного університету оборони України імені Івана Черняховського і “Військово-науковий вісник” Національної академії сухопутних військ імені гетьмана Петра Сагайдачного. Видання вміщують наукові студії 3 історії України, всесвітньої історії, історії Українського війська та сучасних Збройних Сил України, історії розроблення та застосування озброєння та військової техніки.

“Воєнно-історичний вісник” почав видаватися у 2011 році і випускається чотири рази на рік. Кожний номер, як правило, вміщує понад 20 статей, тематично об’єднаних у таких рубриках: “Дослідження, повідомлення”, “Державне управління національною безпекою”, “Військовосоціальне управління”, “Історія науки і техніки”, “Історичні постаті”, “Історія війн і воєнного мистецтва", “Військова техніка та озброєння”.

Видання, що виходить у Львові, засноване у 2000 році і видається два рази на рік, вміщуючи близько 20 статей у таких розділах: “Історія України”, “Всесвітня історія”, “Локальні конфлікти та збройні конфлікти сучасності”, “Наукові огляди, рецензії”. Крім того, одна із непостійних рубрик видання присвячена визначним датам світової та вітчизняної воєнної історії, наприклад, “70-річчя завершення Другої світової війни”, “100-річчя Української революції” тощо [6].

У справі розвитку воєнно-історичної науки, а також популяризації іï здобутків серед української молоді провідне місце належить вітчизняним науковим та музейним установам. У 1997 році в Інституті історії України 
НАН України заснували наукове видання на воєнно-історичну тематику Сторінки воєнної історії України. Збірник наукових праць присвячений малодослідженим подіям історії України періоду Другої світової війни, різним аспектам життя населення під час нацистської окупації: економічним $і$ соціальним проблемам, матеріально-побутовому становищу, моральнопсихологічним настроям населення, а також суспільно-політичним та соціокультурним процесам воєнної і повоєнної доби. Значна увага у збірнику приділена джерелознавчим і методологічним аспектам дослідження історії Другої світової війни та розвитку історіографії. Збірник виходить один раз на рік, кожний номер вміщує близько 20 статей у відповідних тематичних рубриках: “Енциклопедистика”, “Історіографія, методологія, джерелознавство”, “Нацистський окупаційний режим”, “Суспільно-політичні процеси”, “Військова справа”, “Рецензіі”, “Історична пам’ять”, “Публікації джерел”, “Бойові дії на фронтах Другої світової війни”, “Післяокупаційний період” тощо.

Ще одне наукове видання, тематика якого присвячена головним чином історії Другої світової та німецько-радянської війн, - Військово-історичний меридіан Національного музею історії України у Другій світовій війні Меморіального комплексу. Видання засноване у 2013 році і видається щоквартально, винятково в електронному вигляді. Серед інших питань, що висвітлюються на сторінках видання - історія локальних війн і збройних конфліктів XX століття, а також проблеми музеєзнавства. Кожний збірник вміщує до 15 статей за такими рубриками, як "Методологія. Історіографія. Джерелознавство”, “Люди. Події. Факти”, “Грані війни”, “Нацистський окупаційний режим" тощо.

Склад редакційних колегій усіх видань включає фахівців у галузі історичних наук. Видання мають високий науковий рівень, в них розміщують публікації фахівці вищої кваліфікації - кандидати і доктори наук, а також аспіранти, ад'юнкти, докторанти. Видання призначені для наукових, 
науково-педагогічних, музейних та архівних працівників, а також курсантів, слухачів і студентів закладів вищої освіти.

У питанні розвитку вітчизняної воєнно-історичної науки не можна оминути іншу музейну установу - Національний військово-історичний музей. Упродовж п’яти років (2009-2013) музей проводив щорічні наукові конференції з питань воєнної історії різних регіонів України. Початок збройної агресії проти нашої держави зумовив започаткування у 2015 році Всеукраїнської наукової військово-історичної конференції “Війна на Донбасі", присвячену ходу бойових дій, діяльності військових частин (підрозділів) сил безпеки і оборони, проблемам використання озброєння та військової техніки, військовим і цивільним втратам, а також українським героям у російсько-українському збройному протистоянні тощо.

Крім того, з 2000 року двічі на рік музей випускав наукове видання Військово-історичний альманах, призначений як для працівників музейних, архівних і наукових установ, так і для широкого загалу. Змістовно альманах включає такі тематичні рубрики: “Історія”, “Фортифікація”, “Уніформологія”, “Філателія”, “Зброя. Спорядження. Техніка”, “Військовий некрополь”, “Архів”, “Музей”, “Книгозбірня”. Кожен номер вміщує близько 15 статей, найбільше 3 яких входить у рубрику “Історія” (4-8 статей за номер).

Аналіз номерів Військово-історичного альманаху 3 точки зору періодизації воєнної історії України [7] свідчить, що 2\% від усього обсягу статей рубрики “Історія” присвячені періоду Давньої України, 2\% - КиєвоГалицькому періоду, 5\% - добі Гетьманщини, 11\% - рокам російськоавстрійського панування, 5\% - міжвоєнному періоду на західноукраїнських землях, $19 \%$ - періоду національно-визвольних змагань, 28\% - добі радянської влади (з них подіям Другої світової війни - 17\%, діяльності ОУНУПА - 11\%), 6\% - періоду незалежної України, 22\% - інше. Таким чином, тематика статей Військово-історичного альманаху досить широка і охоплює майже усі періоди воєнної історії України. 
Окремої уваги у питанні поширення воєнно-історичних знань серед курсантів вітчизняних ВВНЗ заслуговують видання, які випускають громадські організації, засновані науковцями, зокрема істориками. Серед них науково-популярний журнал “Воєнна історія” та львівський мілітарний альманах “Цитаделя”. Журнал “Воєнна історія” заснований у 2002 році Всеукраїнською громадською організацією "Український інститут воєнної історії” спільно із Національною академію оборони України (нині університет), де і видавався до 2006 року. Авторський колектив включав військових і цивільних істориків, а також фахівців інших галузей знань, головний редактор видання - доктор історичних наук, професор.

Журнал виходив 1-4 рази на рік, кожен номер вміщував до 15 статей, об’єднаних у такі тематичні рубрики, як “Дослідження, повідомлення”, "Постаті”, “Архіви, документи” тощо. Статті охоплювали різні напрями дослідження воєнної історії, а саме: проблеми методології воєнно-історичної науки, історію війн, окремих воєнних кампаній, операцій, досвід застосування збройних сил у локальних війнах, збройних конфліктах, миротворчих та антитерористичних операціях (у тому числі на Сході України), міжнародне військове співробітництво, діяльність видатних історичних діячів, досвід будівництва Збройних Сил України, розвиток озброєння і військової техніки, організацію підготовки, а також військовопатріотичного виховання офіцерського корпусу.

Львівський мілітарний альманах “Цитаделя” заснований у 2009 році благодійним фондом “Філософський проект”. Авторський колектив видання включає професійних істориків, а головний редактор - кандидат філософських наук. У першому номері альманаху редколегія звернулася до читача зазначаючи, що “... воєнні події, активну участь у яких брало багато наших співвітчизників, дивним чином відчужуються від нашої історії. ... вся мілітарна сфера, саме військо сприймаються як щось стороннє” [8, с. 4]. Однак тематика видання обмежена воєнною історією лише західних областей України і майже не висвітлює сучасні події у нашій державі. Альманах 
виходить два рази на рік і включає рубрики: “Воєнна історія”, "Тактика i стратегія”, “Фортифікації”, “Уніформологія”, “Військова символіка”, “Біографістика”, “Озброєння і військова техніка”, “Документ” тощо.

Кожний номер видання налічує близько 10 статей, по 1-2 статті на рубрику. Водночас найбільше статей представлено у рубриці “Воєнна історія" (2-8 за номер). Їхня тематика охоплює різні періоди воєнної історії західного регіону - від наполеонівських війн до Другої світової війни. Зокрема, автори альманаху досліджували вихідців Галичини та Закарпаття у битві при Асперні, національне представництво у збройних силах АвстроУгорщини під час Першої світової війни, перебіг українсько-польської війни, діяльність Української галицької армії, входження Червоної армії до Львова тощо. У рубриці “Біографістика” представлено біографії військових діячів, у тому числі українських, таких як П. Шандрук, О. Букшований, М. Тарнавський та інші. Незначна частина статей присвячена озброєнню i військовій техніці у відповідній рубриці. Проблеми сучасних Збройних Сил України обмежено висвітлюють у рубриці “Військова символіка”.

Кількість випусків наукових періодичних видань України на воєнноісторичну тематику наведено у табл. 1.

Таблиця 1

Кількість випусків наукових видань на воснно-історичну тематику та їх доступність у мережі Інтернет (станом на початок 2019 року)

\begin{tabular}{|c|c|c|c|c|c|c|}
\hline $\begin{array}{c}\text { Воєнно- } \\
\text { історичний } \\
\text { вісник }\end{array}$ & $\begin{array}{c}\text { Військово- } \\
\text { науковий } \\
\text { вісник }\end{array}$ & $\begin{array}{c}\text { Сторінки } \\
\text { воєнної } \\
\text { історії } \\
\text { України }\end{array}$ & $\begin{array}{l}\text { Військово- } \\
\text { історичний } \\
\text { меридіан }\end{array}$ & $\begin{array}{l}\text { Військово- } \\
\text { історичний } \\
\text { альманах }\end{array}$ & $\begin{array}{c}\text { Львівський } \\
\text { мілітарний } \\
\text { альманах } \\
\text { “Цитаделя” }\end{array}$ & $\begin{array}{l}\text { Воєнна } \\
\text { історія }\end{array}$ \\
\hline 20 & 30 & 20 & 24 & 26 & 15 & 80 \\
\hline $\begin{array}{l}\text { у вільному } \\
\text { доступі } \\
\text { (номери } \\
\text { 2011-2016) }\end{array}$ & $\begin{array}{l}\text { у вільному } \\
\text { доступі } \\
\text { (номери } \\
\text { 2017-2019) }\end{array}$ & $\begin{array}{l}\text { у вільному } \\
\text { доступі } \\
\text { (номери } \\
2008- \\
2018)\end{array}$ & $\begin{array}{c}\text { у вільному } \\
\text { доступі всі } \\
\text { номери }\end{array}$ & $\begin{array}{c}\text { у вільному } \\
\text { доступі всі } \\
\text { номери }\end{array}$ & $\begin{array}{c}\text { відсутній у } \\
\text { вільному } \\
\text { доступі } \\
\text { (всі номери } \\
\text { платні) }\end{array}$ & $\begin{array}{c}\text { у вільно- } \\
\text { му } \\
\text { доступі } \\
\text { (номери } \\
\text { 2002- } \\
\text { 2012) } \\
\end{array}$ \\
\hline
\end{tabular}

Окреме місце у поширенні воєнно-історичних знань серед курсантів вищих військових навчальних закладів належить збірникам матеріалів 
наукових воєнно-історичних конференцій. Відповідно до щорічних Планів воєнно-історичної роботи у Збройних Силах України у військових навчальних закладах у 2017 році було проведено 7 конференцій на воєнноісторичну тематику, у 2018 - 5, у $2019-6$.

32016 року у Національному університеті оборони України імені Івана Черняховського щорічно проводиться Всеукраїнська наукова конференція “Українське військо: сучасність та історична ретроспектива”, присвячена військовій справі та діяльності військових формувань на теренах України від давніх часів до сьогодення. Секції конференції охоплюють широкий спектр тем - від військової організації скіфського царства до застосування сил безпеки і оборони в антитерористичній операції та операції Об'єднаних сил на Сході України.

Найбільше подібних заходів організовує і проводить Національна академія сухопутних військ імені гетьмана Петра Сагайдачного. Тематика конференцій присвячена різноманітним аспектам історії України: проблематиці національно-визвольних змагань ("Українське військо в Національній революції 1917-1921 рр. (до 100-річчя армії УНР)”, розвитку воєнного мистецтва, озброєння і військової техніки (“Людина і техніка у визначних битвах світових воєн XX століття"), радянській репресивній політиці як інструменту знищення української науки, культури та історичної спадщини (“Великий терор і масові репресії в Україні (20-50-ті рр. ХХ століття”) тощо.

За результатами роботи конференцій організатори випускають збірники матеріалів, поширюючи їх серед бібліотек вищих військових начальних закладів або у вільному доступі у мережі Інтернет в електронному вигляді. Матеріали конференцій призначені для широкого кола читачів науковців, викладачів, курсантів і слухачів вищих військових навчальних закладів. Крім того, організатори заходів дають змогу самим курсантам опублікувати тези доповідей, зокрема за досвідом їх участі в антитерористичній операції/операції Об’єднаних сил на Сході України [9]. 
У питанні поширення воєнно-історичних знань окремо варто розглянути видання, що випускають ветеранські організації України. Тематика цих видань головним чином присвячена подіям часів Другої світової війни, зокрема ії складовій - німецько-радянській війні 1941-1945 років. Серед них Альманах Київської міської асоціації ветеранів-підводників, історичний альманах Ради організації ветеранів України “Патріот України”, “Записки военно-исторического общества" тощо. Альманахи виходять не періодично, часто напередодні пам'ятних та ювілейних дат. Змістове наповнення видань зазвичай включає спогади, статті членів ветеранської організації і подекуди професійних істориків.

Альманах Київської міської асоціації ветеранів-підводників - видання на вузько спеціалізовану тему і присвячене головним чином створенню $\mathrm{i}$ діяльності військово-морського флоту радянських збройних сил. Альманах вміщує біографії, спогади про військову службу, статті, присвячені морським боям під час російсько-японської та Другої світової війн, особливостям військової служби в роки “холодної війни”, розвитку та застосування озброєння та військової техніки тощо. Видання може слугувати тим, хто цікавиться військово-морською тематикою, зокрема історією становлення, розвитку, повсякденної діяльності i досвіду застосування військовоморського флоту Російської імперії та Радянського Союзу [10].

У свою чергу, тематика історичного альманаху Ради організації ветеранів України обмежена лише подіями німецько-радянської війни. Статті альманаху можуть бути корисними як приклад усної історії під час дослідження переломних подій періоду Другої світової війни на східноєвропейському театрі воєнний дій: Курської битви, битви за Дніпро, визволення українських міст тощо. Водночас варто враховувати, що спогади безпосередніх учасників і свідків тих подій, зазнавши зовнішніх впливів на формування історичної свідомості, демонструють трансформаційні процеси індивідуальної пам'яті та подекуди носять міфологізований характер. Крім того, статтям альманаху притаманні штампи радянської i російської 
пропаганди про всесвітньо значущу роль Радянського Союзу у перемозі 1945 року, “дружбу народів” тощо. Серед суто історичної тематики на сторінках видання періодично порушується питання проблем історичної пам'яті та патріотичного виховання української молоді на основі воєнної історії України. При цьому спроби українських науковців переглянути чи здійснити переоцінку тогочасних подій або персоналій автори альманаху сприймають як “культивування в Україні націоналістичних ідей”.

Зокрема, у номері за 2011 рік вміщено статтю, де стверджувалося, що політика історичної пам’яті в Україні “в цілях націоналістичної кон'юнктури призвела до підміни понять і оцінок, пов'язаних з ... війною”. У статті автор наполягав, що “створюється нова історія України у контексті тотальної українізації”, а також пропонував протидіяти цьому процесу “спільними зусиллями Білорусі, Росії та України, узгодивши офіційні трактування війни, навчальні програми, підручники з історії” [11, с. 84,92]. У свою чергу, у номері за 2013 рік було надруковане звернення до тодішнього Президента України В. Януковича 3 приводу того, що “... в деяких областях Західної України увіковічують пам'ять вояків УПА, які служили на боці німецьких загарбників, будують пам'ятники їм, перейменовують вулиці на їх честь, що принижує гідність ветеранів Великої Вітчизняної війни ...”, а також закликали посилити відповідальність за телепередачі, які “спотворюють правду історії Великої Вітчизняної війни, ... ображають живих учасників бойових дій, згубно впливають на патріотичне виховання ... молоді" $[12$, c. 10$]$.

У тематичному номері “Патріота України”, присвяченому 60-річчю від дня перемоги, серед матеріалів про знакові події німецько-радянської війни (оборона Одеси і Севастополя, Корсунь-Шевченківська і Київська наступальна операції тощо) варто відмітити статтю про проблеми патріотичного виховання молоді в Україні. Зокрема, автор негативно “оцінював” руйнування системи патріотичного виховання, що склалася в Радянському Союзі. При цьому витоками патріотизму автор вважав визнання 
того, що незалежна Україна $є$ правонаступницею Української Радянської Соціалістичної Республіки, а справжня незалежність України була досягнута “в результаті Перемоги над фашизмом у Великій Вітчизняній війні 19411945 років" [13, с. 91, 93].

Ще одним виданням, до складу редакційної колегії якої входили переважно члени ветеранських організацій, було “Записки военноисторического общества”. Видання засноване у 2001 році так званим воєнно-історичним товариством при громадській організації “Російськоанглійський університет імені Володимира Мономаха” для “...сприяння тим, хто навчається у середніх і вищих навчальних закладах України, у вивченні історії Росії та України”. Тематика видання також здебільшого присвячена історії "Великої Вітчизняної війни”. Однак, окрім суто радянських кліше, статтям була притаманна завуальована пропагандистська антиукраїнська риторика, розгляд історії України, у тому числі іiї воєнної складової, винятково у контексті історії Росії [14].

Таким чином, аналіз змісту видань, які випускають ветеранські організації України, дає підставу стверджувати, що їм притаманна певна тенденційність в оцінюванні тих чи інших подій Другої світової війни, зокрема висвітлення їх у руслі радянської і сучасної російської історіографії, а саме: використання словоформи “Велика Вітчизняна війна”, висвітлення іiі як центральної події в усій історії України, відсутність згадок про інші історичні періоди нашої держави, термінологічна плутанина у поняттях “фашизм” і “нацизм” в оцінці державної ідеології тогочасної Німеччини, уникання згадок про початок Другої світової війни, “виключаючи” із історичного контексту західні області України, населення якого стикнулося 3 війною у 1939 році, неприйняття діяльності Української повстанської армії та інших військових формувань на Заході України у воєнний і післявоєнний періоди тощо.

При цьому автори цих видань періодично порушують питання військово-патріотичного виховання української молоді, у тому числі на 
основі воєнної історії України. Автори статей закликають молодь пам'ятати і відзначати історичні дати, відвідувати пам’ятні місця, доглядати та впорядковувати могили захисників Вітчизни тощо. Однак вони акцентують увагу лише на глорифікації подій 1941-1945 років XX століття, без урахування інших періодів української державності і вшанування інших борців за незалежність України.

Такий стан справ частково зумовлений суперечливою політикою держави щодо питань історичної пам'яті, відсутністю протягом довгого часу якісного інформаційного простору, що призвело до інформаційної експансії з боку Російської Федерації. На думку вітчизняних науковців, за всі роки незалежності питання моделювання формату пам’яті про війну, прийнятного для усієї України, так і не було врегульовано, “... розставляючи час від часу діаметрально протилежні аксіологічні маркери - від С. Бандери ... за президента В. Ющенка до “Алеї Героїв Радянського Союзу” ... за президента В. Януковича - влада займалася радше політиканством ...” [15, с. 14].

Початок російської збройної агресії проти України спонукав переглянути політику історичної памяті, почалися пошуки більш прийнятного формату, який би поєднував комеморативні потреби усього українського суспільства і водночас сприяв інтеграції України у світову та європейську практику комеморації. Зокрема, було видано низку нормативноправових актів, виконання яких має сприяти об'єктивному та всебічному дослідженню історії Другої світової війни, недопущенню іiі фальсифікації у наукових дослідженнях, навчально-методичній літературі, підручниках, а також донесенню до широкої громадськості інформації про звитяги Українського народу у визвольній боротьбі, його визначний внесок у перемогу Антигітлерівської коаліції. Крім того, виняткового значення набуває реалізація заходів, спрямованих на консолідацію українського суспільства, налагодження громадянського взаєморозуміння і примирення у питаннях національної історії, а також патріотичного виховання курсантів 
вітчизняних ВВНЗ на прикладах доблесті та звитяги Українського війська у різні періоди Української державності [16].

Висновок. Таким чином, вітчизняні періодичні видання на воєнноісторичну тематику мають значний потенціал у поширенні воєнноісторичних знань і популяризації воєнної історії України у ході військовопатріотичного виховання курсантів вітчизняних ВВНЗ. Використання періодичних наукових видань у навчально-виховному процесі як додаткових джерел пізнання дасть змогу ознайомити курсантів із результатами сучасних наукових досліджень, озброїти знаннями про ті чи інші історичні явища, їх причини та наслідки для осмислення подій, що відбуваються сьогодні у нашій державі, а також сприятиме формуванню патріотичної свідомості майбутніх офіцерів в умовах триваючої збройної агресії проти України. Крім того, курсанти - учасники бойових дій також можуть виступити носіями воєнно-історичних знань. Участь їх у наукових конференціях, семінарах, круглих столах, що проводяться у вищих військових навчальних закладах, сприятиме поширенню прикладів усної історії у збірниках матеріалів конференцій.

Аналіз видань, присвячених воєнній історії України, свідчить, що їхня тематика дещо варіюється, залежно від спеціалізації установ, які їх випускають, i частково зумовлюється регіональними та ідеологічними особливостями. “Сторінки воєнної історії України” і “Військово-історичний меридіан" як видання наукових установ зосереджуються головним чином на грунтовному дослідженні історії Другої світової війни. "Воєнно-історичний вісник" і “Військово-науковий вісник” видаються у вищих військових навчальних закладах, тому охоплюють більш широку тематику, окремо досліджуючи будівництво i розвиток Збройних Сил України, досвід застосування їх у міжнародних миротворчих операціях та антитерористичній операції/операції Об'єднаних сил на Сході України тощо. Проблематика статей видання музейної установи “Військово-історичний альманах" також не обмежується лише одним історичним періодом, а охоплює різні 
хронологічні межі вітчизняної воєнної історії. Журнал Інституту воєнної історії України "Воєнна історія” вміщує статті на широку тематику, а наукові студії присвячені майже всім періодам воєнної історії України - від давніх часів до сучасності, у той час як львівський мілітарний альманах “Цитаделя" спеціалізується переважно на регіональній воєнній історії. У свою чергу, видання, які випускають ветеранські організації, попри надмірну ідеалізацію конкретного історичного періоду та його діячів, можуть стати додатковим джерелом воєнно-історичних знань про окремі події Другої світової війни.

Виявлено низку тенденцій розвитку періодичних видань на воєнноісторичну тематику за роки незалежності України, а саме:

акцентуація видань ветеранських організацій винятково на проблематиці німецько-радянської війни у дусі радянської та сучасної російської пропаганди;

висвітлення збройної агресії Російської Федерації проти України, а також подій, пов'язаних із окупацією Автономної Республіки Крим, переважно виданнями вищих військових навчальних закладів;

посилення національно-патріотичної складової наукових періодичних видань, спрямованість на розвінчування радянських, а також російських кліше та стереотипів щодо воєнної історії України;

доступність майже усіх воєнно-історичних періодичних видань України через мережу Інтернет у результаті розвитку інформаційних технологій.

Водночас у справі поширення воєнно-історичних знань залишається низка проблемних питань, що потребують вирішення. Сучасна воєнна історія України (окупація Автономної Республіки Крим, російська збройна агресія проти України) майже не знаходить свого висвітлення у згаданих виданнях. Деякі питання досвіду застосування сил безпеки i оборони в антитерористичній операції/операції Об’єднаних Сил частково досліджувалися у “Воєнно-історичному віснику”, “Військово-науковому віснику”, а також журналі “Воєнна історія” [17]. Разом $з$ тим найбільше 
історичних досліджень на тему перебігу збройного конфлікту на Сході України можна знайти на сторінках збірників матеріалів наукових воєнноісторичних конференцій. Крім того, в умовах інформаційної агресії Російської Федерації дедалі більшого значення набуває протидія пропаганді антиукраїнського характеру на сторінках видань деяких громадських, зокрема ветеранських, організацій України.

Таким чином перспективними напрямами діяльності у справі поширення воєнно-історичних знань серед курсантів вітчизняних вищих військових навчальних закладів залишається посилення уваги вітчизняних науковців до проблематики сучасної збройної агресії Російської Федерації проти України, а також спрямування зусиль на розвінчування міфів i протидію фальсифікаціям у питаннях воєнної історії України як Давніх часів, так і сьогодення.

\section{Список використаних джерел і літератури}

1. Історія Українського війська Т.1. [І. Крип’якевич, Б. Гнатевич, 3. Стефанів, О. Думін, С. Шрамченко]. - 5-е вид., змін. і доп. - К. : Вид-во "Варта", 1994. - 384 с.

2. Зубков A.A. Формирование военно-патриотической воспитанности военнослужащих в советский и постсоветский периоды (1941-2004 гг.) : автореф. дисс. ... канд. пед. наук : 13.00.01 - общая педагогика, история педагогики и образования ; 13.00 .08 - теория и методика профессионального образования // Андрей Аркадьевич Зубков ; Калининградский государственный университет. - Калининград, 2004. - 20 с.

3. Бідний В.А., Гребенюк М.В., Грииюк В.М. Роль та місце воєнноісторичної роботи за кордоном (на прикладі США та Росії) / В. А. Бідний, М. В. Гребенюк， В.М.Грицюк // Наукові праці Кам'янець-Подільського національного університету імені Івана Огієнка. - 2016. - Т. 26. - С. 94-104.

4. Біла книга спеціальних інформаційних операцій проти України 2014-2018 / Д. Ю. Золотухін. - К., 2018. - 384 с. 
5. Воєнно-історична наука в Україні: стан і перспективи : матеріали круглого столу (Київ, 30 травня 2001 р.). - К. : Інститут історії України НАН України, 2001. - 79 с.

6. Військово-науковий вісник. - Львів : НАСВ, 2015. - Вип. 24. - 253 с.; Військово-науковий вісник. - Львів : НАСВ, 2018. - Вип. 30. - 257 с.

7. Концепція воєнної історії України, затверджена Міністром оборони України 08.12.2017 p.

8. Цитаделя : львівський мілітарний альманах. - Львів : Вид-во “Астролябія”, 2009. - Ч. 1. - 96 с.

9. Дзьоба М.В. Бій за Ямпіль очима учасника / М.В. Дзьоба // III Всеукраїнська наук.-практ. конф. "Українське військо: сучасність та історична ретроспектива" : зб. матеріалів (Київ, 30 листопада 2018 р.). - К. : НУОУ, 2018. - С. 69-71; Пристайчук Ю.В. Деякі аспекти культурологічних особливостей зони АТО та ООС і їх врахування командуванням в ході проведення операцій / Ю.В.Пристайчук // III Всеукраїнська наук.-практ. конф. "Українське військо: сучасність та історична ретроспектива" : зб. матеріалів (Київ, 30 листопада 2018 р.). - К. : НУОУ, 2018. - С. 98-100.

10. Альманах Киевской городской ассоциации ветеранов-подводников. - К. : Вид-во “Макком”, 2008. - 191 с.

11. Пироженко В.A. Великая Отечественная война и галицкие коллаборационисты в политике исторической памяти в Украине / В. А. Пироженко // Патріот України : історичний альманах / Редкол.: Цибенко П. С. (голова) та ін. - К. : Вид-во “Україна”. - Вип. 10. - 2011. C. 84-92.

12. Патріот України : історичний альманах (Спогади учасників визволення України) / Редкол.: Цибенко П. С. (голова) та ін. - К. : Вид-во "Україна". - Вип. 14. - 2013. - 84 с.

13. Ясєв Г.Є. Наявні проблеми патріотичного виховання / Г. Є. Ясєв // Патріот України. До 60-річчя Перемоги у Великій Вітчизняній війні : 
довідково-інформаційне видання. - К. : Пошуково-видавниче агентство “Книги Пам’яті України”, 2003. - С. 91-96.

14. Записки военно-исторического общества. - К., 2001. - № 1. - 100 с.

15. Лисенко О.Є. 9 травня як предмет наукових досліджень і сегмент політики пам’яті / О. Є. Лисенко // Міжнарод. наук. конф. “Травень 1945 року у науковому дискурсі, національній свідомості та історичній пам'яті” : зб. матеріалів (Київ, 29 квітня 2015 р.). - К. : НУОУ, 2015. - С. 12-14.

16. Про заходи з відзначення у 2015 році 70-ї річниці перемоги над нацизмом у Європі та 70-ї річниці завершення Другої світової війни : Указ Президента України від 23.03.2018 № 2630-VIII // Урядовий кур’єр. - 2015. № 55 (26.03.2015); Про засудження комуністичного та націоналсоціалістичного (нацистського) тоталітарних режимів в Україні та заборону пропаганди їхньої символіки : Закон України від 09.04.2015 № 317-VIII // Урядовий кур'єр. - 2015. - № 90 (22.05.2015); Про правовий статус та вшанування пам'яті борців за незалежність України у XX столітті : Закон України від 09.04.2015 № 314-VIII // Урядовий кур’єр. - 2015. № 93 (27.05.2015); Про увічнення перемоги над нацизмом у Другій світовій війні 1939-1945 років : Закон України від 09.04.2015 № 315-VIII // Урядовий кур’єр. - 2015. - № 93 (27.05.2015); Про заходи з відзначення 100-річчя подій Української революції 1917-1921 років : Указ Президента України від 22.01.2016 №17 // Урядовий кур’єр. - 2016. - № 16 (27.01.2016).

17. Харук A.I. Деякі аспекти висвітлення у зарубіжній періодиці участі української авіації в антитерористичній операції на Сході України (за публікаціями 2014 р.) / А. І. Харук // Військово-науковий вісник. - Львів : НАСВ, 2015. - Вип. 24. - С. 206-218; Грицююк В. М. Розгортання воєнного конфлікту на Сході України (весна 2014 року) / В. М. Грицюк // Воєнна історія України, 2016. - № 1 (80). - С. 64-69; Топальський В. Л. Особливості використання і втрати армійської авіації Сухопутних військ Збройних Сил України у ході Антитерористичної операції / В. Л. Топальський // Воєнна історія України, 2016. - № 1 (80). - С. 70-79. 
Pashkova O. O., Researcher of Research Division of Research Center of Military History of Ivan Cherniakhovskyi National Defence University of Ukraine (Kyiv)

\section{MILITARY-HISTORICAL PERIODICALS IN MILITARY-PATRIOTIC EDUCATION OF CADETS OF HIGHER MILITARY EDUCATIONAL INSTITUTIONS}

The article deals with the condition of national scientific periodicals on military-historical topics. The creation and development of periodicals of educational and scientific institutions, as well as public (veteran) organizations of Ukraine are investigated. The content of these publications and their potential in disseminating military-historical knowledge and popularizing the military history of Ukraine among cadets of domestic higher military educational institutions are analyzed.

Key words: scientific periodicals, military history of Ukraine, militaryhistorical knowledge, cadets, higher military educational institutions. 